\title{
The Effect of Foreign Direct Investment on Sustainable Development ASEAN 3 and ASEAN 5: A Conceptual Study
}

\author{
Irwan Yusof ${ }^{1}$, Azlinah Ambak ${ }^{2}$, Sulaiman Yamin ${ }^{3}$ and Norafzan Awang ${ }^{4}$ \\ \{ irwanyusof@yahoo.com¹, azlinahktb@yahoo.com², sulaimanyamin2@gmail.com³, \\ afzan@ucbestari.edu.my ${ }^{4}$ \} \\ 1,2,3,4 University College Bestari, Terengganu, Malaysia
}

\begin{abstract}
Sustainable development is part of ASEAN 2025 vision. It is actively debated amongst ASEAN leaders due to the economic fluctuation, increasing in environmental pollution and wide income gap in ASEAN countries that can hinder the achievement of sustainable development. Therefore this study tries to analyse three indicators of sustainable development which are economic, environment and income distribution and the effect of foreign direct investment on these three indicators between ASEAN3 (Cambodia, Laos and Vietnam) and ASEAN5 (Malaysia, Indonesia, Philippines, Thailand and Singapore) based on the different levels of economic growth. Foreign direct investment is expected to have a different impact on the three indicators of sustainable development due to the different economic levels between ASEAN 3 and ASEAN 5. Previous researches have failed to show a consistent relationship between foreign direct investment and the three indicators of sustainable development. Moreover previous researches mostly looks at the effects of foreign direct investment on each individual indicator of sustainable development separately, but very little is done comprehensively by looking at the effects of foreign direct investment on all three sustainable development indicators. Especially on the comparative impact on ASEAN 3 and ASEAN 5. This paper is based on extensive literature. It is expected to prove that the dominant effect of foreign direct investment towards sustainable development and the effect might be different between ASEAN3 and ASEAN5 countries. Future studies should validate empirically the proposed research framework.
\end{abstract}

Keywords: sustainable development, FDI, economic, environment qulity, income inequlity

\section{Introduction}

(Commission on Environment, 1987) has stated that "sustainable development (SD) is a development that meets current needs without affecting the ability of future generations to meet their needs". (Summit on Sustainable Development, 2002) outlines three important indicators that are fundamental to SD: social, environment and economic. SD is one of the key agenda for ASEAN leaders because it is a part of ASEAN vision 2025. Issues of global warming are not only globally, but also at ASEAN level can be stunted to achieve SD. The release of carbon dioxide (CO2) is the most important contributor to global warming and climate change (Watson et al., 1997). (Birol, 2015) said ASEAN contributed to CO2 emission of $4 \%$ in 2013 and it is expected to double in 2040. A study by (Rasiah et al., 2016), said that if there is no optimum policy and action to be taken, then the cumulative cost of damage due to climate change to ASEAN will reach RM40.1 billion from 2010 to 2110. (OECD, 2013) also gives a serious concern on the issues of income distribution gap that seems increasing over time. 
In order to achieve SD, it is necessary to examine the determinant factors of SD and one of them is foreign direct investment (FDI). It is according to (Unctad, 2014) which believes that FDI has great potential to achieve SD. It is also supported by previous studies showing a shift in perspective between policy makers in the country which examined in promoting and attracting more FDI inflows to create opportunities and assist developing countries to achieve SD (Erdal and Tatoglu, 2002; Cassidy and Andreosso-O'Callaghan, 2006).

Therefore, this study is carried out by analyzing previous studies in order to determine the effects of FDI on three SD indicators namely social, environment and economic, specifically on ASEAN 3 and ASEAN 5. The proposed study will be conducted by dividing ASEAN countries into two groups based on the level of ASEAN 3 (Vietnam, Cambodia and Laos) and ASEAN 5 (Malaysia, Thailand, Indonesia, Singapore, and Philippines) according to different levels of economic (Xaypanya, Rangkakulnuwat and Paweenawat, 2015). Due to different levels of economic, thus the effects of FDI on these SD indicators might also be different.

Previous studies have failed to show a consistent relationship between FDI and these three indicators of SD, thus, it requires a further study to investigate more details on this relationship. Furthermore previous studies also look at the effects of FDI on each indicators of SD separately, but very little research is made by looking at the effects of FDI with all these three indicators of SD comprehensively. Moreover, this study might also examine the comparative impact on ASEAN 3 and ASEAN 5.

\section{Literature Review}

\subsection{Foreign Direct Investmen and Economic Growth}

In recent study by (Sirag, SidAhmed and Ali, 2018) showed that FDI inflows positively effect on economic growth through financial development in Sudan. The study used annual data from 1970 to 2014. Moreover, it is supported by a study from (Ridzuan et al., 2017) which also showed a positive impact between FDI inflows and economic growth in Malaysia based the annual data from 1970 to 2013. Meanwhile a study from (Koroci, 2018)showed a strong positive relationship between FDI inflows and economic growth in Albania. Furthermore, it also showed that FDI would increase investments in export sectors which transfer new technologies, expertise and management and also would increase competition in the market as according to the survey data is from 1995 to 2012. Meanwhile a study by (Gural and Lomachynska, 2017) showed a positive relationship between FDI and economic growth. The study used annual data from 1992 to 2016 for V4 countries (Poland, Czech Republic, Hungary, and Slovak Republic). Likewise, other studies also showed that FDI inflows positively effect on economic growth (Belloumi, 2014; Solarin and Shahbaz, 2015; Iamsiraroj, 2016; Parezanin, Jednak and Kragulj, 2016).

However, a study from (Florence, David and Daniel, 2017) showed that FDI inflows negatively impact on economic growth, exports, inflation and benefits in Nigeria which used annual data from 1984 to 2015. The study is supported by (Chansomphou and Ichihashi, 2011) that showed FDI negatively impacting economic development in Laos. Moreover, the study summarized the negative effects of FDI probably due to the insistense on some sectors of the economy that have been extremely increasing and decreasing over a certain period of time.

Meanwhile a study from (Klasra, 2011)showed that FDI inflows has no significant relationship between economic growth in Turkey and Pakistan and the studies used annual 
data from 1975 to 2004 that were supported by previous studies(Azman-Saini, Law and Ahmad, 2010; Ridzuan et al., 2017).

\subsection{Foreign Direct Investments and Environment Quality}

A study from (Ridzuan et al., 2017) which used time series data in Malaysia from 1970 to 2013 (44 years) concluded that FDI inflows had a positive impact on the environment quality. Hence the higher the inflow of FDI, the lower the pollution in the country as the quality of pollution is measured through $\mathrm{CO} 2$ emissions. This highlight is supported by a study by (Ridzuan et al., 2017) whereby the annual survey data for the Singapore was taken from 1970 to 2013 (44 years). While a study from (Cătălin Voica, Panait and Haralambie, 2015) showed a positive impact on FDI on environmental quality whereby the study used annual data of $28 \mathrm{EU}$ member states for a certain of period since 2000 to 2012. Furthermore, other studies showed positive FDI effects on environmental quality through the transfer of environment-friendly technology from developed countries to less developed countries (Kirkulak, Qiu and Yin, 2011; Leiter, Parolini and Winner, 2011; Al-mulali and Foon Tang, 2013).

Nevertheless, (Kaur, 2013) study was conducted in India showed the opposite effect whereby FDI inflows negatively affect the quality of the environment in which FDI is responsible for increasing $\mathrm{CO} 2$ emissions. The study was based on the annual data that was taken in India from 2000 to 2015 (15 years). Moreover, the study was supported by (Behera and Dash, 2017) showed that FDI inflows negatively affect on environmental quality for both high and middle-income countries whereas there is no significant relationdhip between FDI inflows and environment quality for low-income group. (Abdouli and Hammami, 2017) also pointed out that FDI negatively affects the quality of the environment based on selected annual data from 17 selected MENA countries from the period of 1971 to 2013. Moreover other studies also showed the negative effects of FDI on environmental quality(Chakraborty and Mukherjee, 2013; Lau, Choong and Eng, 2014; Omri, Nguyen and Rault, 2014).

Meanwhile the studies from (Jugurnath, Roucheet and Teeroovengadum, 2017) showed that FDI inflows has no significant relationship between environment quality. The study used the data panels from 18 European countries for the period of 1995 to 2013. It is supported by (Shahidan Shaari et al., 2014) through the review data from 1992 to 2012 for 15 developing countries which also showed that FDI did not affect the quality of the environment. Even from other supporting studies which are from (Atici, 2012; Chandran and Tang, 2013).

\subsection{Foreign Direct Investments and Income Inequality}

In a study by (Ridzuan et al., 2017) which concluded that inflows of foreign direct investment can improve the income distribution for Malaysia, which means, FDI indlows negatively impacts on income inequality. This means that the higher the FDI inflows, the smaller the income distribution gap. It is supported by (Balcioglu, 2018) which concluded that on average, the inflows and outflows of FDI inflows negatively impact on long-term income inequality. However, in the short term the impact of FDI inflows and income inequality is positive. The study used the panel cointegration analysis to show correlation between FDI and income inequality for sample of seven countries (Turkey, Azerbaijan, Georgia, Kazakhstan, Kyrgyzstan, Turkmenistan and Uzbekistan) with annual data from 19922012 ( 21 years). Moreover other studies have also shown a negative impact between FDI inflows and income inequality (Wu and Hsu, 2012; Ucal et al., 2014; Mihaylova, 2015). 
Nevertheless a study from (Ngwakwe and Dzomonda, 2018) showed that the increase in FDI inflows had a positive impact on income inequality. The study showed that the increase in FDI inflows had worsened the distribution of income in the country based on annual data taken that were from 2005 - 2015 (15 years). This study is also supported by (Ridzuan et al., 2017) which showed the positive impact between FDI and income inequality in Singapore. While the study from (Cho and Ramirez, 2016) resulted the impact of FDI and FDI stock inflows on income distribution to seven Southeast Asian countries comprising Cambodia, Indonesia, Laos, Malaysia, Philippines, Thailand, and Vietnam which have summed up the increase in FDI inflows will affect income distribution within that group of countries. The study showed that the impact of FDI on income inequality was positive based on annual data taken from 1990 to 2013. Even other past surveys also showed positive effects between FDI inflows and income inequality are (Ahmad and Bahauddin, 2014; Herzer, Hühne and Nunnenkamp, 2014; Munir and Sultan, 2017).

The proposed research framework is developed from extensive review from previous literature and data as seen in figure 1

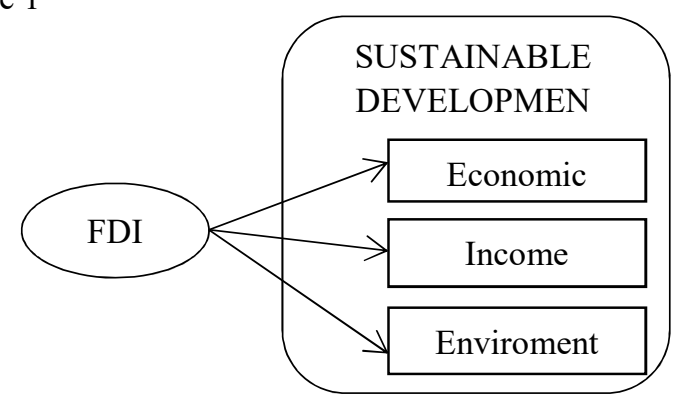

Fig. 1. Research Framework

\section{Research Content Analysis}

The proposed research framework is developed from extensive review from previous literature and findings. The sources of searching literature and findings are from conceptual and empirical papers of quality journals. Google search and digital library are very helpful medium to access the papers and moreover, the literature and findings were collected from the official website.

\section{Discussion And Conclusion}

The main objective of the study is to examine the impact of FDI on three SD indicators, namely economic growth, income inequality and enviroment quality on ASEAN 3 and ASEAN 5. This is due to the different economic levels of both groups of the countries (Xaypanya, Rangkakulnuwat and Paweenawat, 2015). Thus the FDI effects on three indicators of SD are also expected to differ.

Previous studies clearly showed inconsistent results and this encourages this study to be conducted for further investigation of FDI effects on three indicators of SD. Furthermore, only a few studies have been made by looking at the effects of FDI inflows on three indicators of SD especially in a comprehensive study between ASEAN 3 and ASEAN 5. Future studies should validate empirically the proposed research framework. If the proposed framework is validated, the finding of this study is expected to provide useful information to policymakers 
from these two national groups in determining the economic openness policy to achieve SD by 2025 .

\section{References}

[1] Abdouli, M. and Hammami, S. (2017) 'Economic growth, FDI inflows and their impact on the environment: an empirical study for the MENA countries', Quality \& Quantity. Springer Netherlands, 51(1), pp. 121-146. doi: 10.1007/s11135-015-0298-6.

[2] Ahmad, K. and Bahauddin, muhammad kashif N. (2014) 'Impact of FDI on Income Distribution in Selected SAARC Countries', Journal of Applied Environmental and Biological Sciences, 4(July), pp. 1-10.

[3] Al-mulali, U. and Foon Tang, C. (2013) 'Investigating the validity of pollution haven hypothesis in the gulf cooperation council (GCC) countries', Energy Policy. Elsevier, 60, pp. 813-819. doi: 10.1016/J.ENPOL.2013.05.055.

[4] Atici, C. (2012) 'Carbon emissions, trade liberalization, and the Japan-ASEAN interaction: A group-wise examination', Journal of the Japanese and International Economies. Academic Press, 26(1), pp. 167-178. doi: 10.1016/J.JJIE.2011.07.006.

[5] Azman-Saini, W. N. W., Law, S. H. and Ahmad, A. H. (2010) 'FDI and economic growth: New evidence on the role of financial markets', Economics Letters. NorthHolland, 107(2), pp. 211-213. doi: 10.1016/J.ECONLET.2010.01.027.

[6] Balcioglu, H. (2018) 'The Impacts of Inward and Outward FDI on Income Inequality in Turkey and Selected Turkic Republics', Ecoforum Journal, 7(1), pp. 1-8.

[7] Behera, S. R. and Dash, D. P. (2017) 'The effect of urbanization, energy consumption, and foreign direct investment on the carbon dioxide emission in the SSEA (South and Southeast Asian) region', Renewable and Sustainable Energy Reviews. Pergamon, 70, pp. 96-106. doi: 10.1016/J.RSER.2016.11.201.

[8] Belloumi, M. (2014) 'The relationship between trade, FDI and economic growth in Tunisia: An application of the autoregressive distributed lag model', Economic Systems. North-Holland, 38(2), pp. 269-287. doi: 10.1016/J.ECOSYS.2013.09.002.

[9] Birol, F. (International E. A. (2015) Southeast Asia Energy Outlook World Energy Outlook Special Report. Available at: www.iea.org/t\&c/ (Accessed: 18 January 2019).

[10] Cassidy, J. F. and Andreosso-O'Callaghan, B. (2006) 'Spatial determinants of Japanese FDI in China', Japan and the World Economy. North-Holland, 18(4), pp. 512-527. doi: 10.1016/J.JAPWOR.2004.11.004.

[11] Cătălin Voica, M., Panait, M. and Haralambie, G. A. (2015) 'Economic InsightsTrends and Challenges The Impact of Foreign Direct Investment on Sustainable Development', Economic Insights - Trends and Challenges, 4, pp. 89-103. Available at: http://www.upg-bulletin-se.ro/archive/2015-3/10.Voica_Panait_Haralambie.pdf (Accessed: 18 January 2019).

[12] Chakraborty, D. and Mukherjee, S. (2013) 'How do trade and investment flows affect environmental sustainability? Evidence from panel data', Environmental Development. Elsevier, 6, pp. 34-47. doi: 10.1016/J.ENVDEV.2013.02.005.

[13] Chandran, V. G. R. and Tang, C. F. (2013) 'The impacts of transport energy consumption, foreign direct investment and income on CO2 emissions in ASEAN-5 economies', Renewable and Sustainable Energy Reviews. Pergamon, 24, pp. 445-453. doi: 10.1016/J.RSER.2013.03.054.

[14] Chansomphou, V. and Ichihashi, M. (2011) Foreign aid, foreign direct investment and economic growth of Lao PDR, IDEC DP2 Series. Hiroshima University, Graduate 
School for International Development and Cooperation (IDEC). Available at: https://econpapers.repec.org/paper/hiridecdp/1-2.htm (Accessed: 18 January 2019).

[15] Cho, H. C. and Ramirez, M. D. (2016) 'Foreign Direct Investment and Income Inequality in Southeast Asia: a Panel Unit Root and Panel Cointegration Analysis, 1990-2013', Atlantic Economic Journal. Springer US, 44(4), pp. 411-424. doi: 10.1007/s11293-016-9521-7.

[16] Commission on Environment, W. (1987) Report of the World Commission on Environment and Development: Our Common Future Towards Sustainable Development 2. Part II. Common Challenges Population and Human Resources 4. Available at: http://www.un-documents.net/our-common-future.pdf (Accessed: 18 January 2019).

[17] Erdal, F. and Tatoglu, E. (2002) LOCATIONAL DETERMINANTS OF FOREIGN DIRECT INVESTMENT IN AN EMERGING MARKET ECONOMY: EVIDENCE FROM TURKEY, Multinational Business Review. Available at: http://citeseerx.ist.psu.edu/viewdoc/download?doi=10.1.1.456.4487\&rep=rep1\&type=p df (Accessed: 18 January 2019).

[18] Florence, O. O., David, K. K. and Daniel, O. I. (2017) Determinants of Foreign Direct Investment and Its Causal Effect on Economic Growth in Nigeria, KCA Journal of Business Management. KCA University. Available at: https://www.ajol.info/index.php/kjbm/article/view/158219 (Accessed: 18 January 2019).

[19] Gural, A. and Lomachynska, I. (2017) 'FDI AND FINANCIAL DEVELOPMENT AS DETERMINANTS OF ECONOMIC GROWTH FOR V4 COUNTRIES', Baltic Journal of Economic Studies, 3(4), pp. 59-64. doi: 10.30525/2256-0742/2017-3-4-5964.

[20] Herzer, D., Hühne, P. and Nunnenkamp, P. (2014) 'FDI and Income InequalityEvidence from Latin American Economies', Review of Development Economics. John Wiley \& Sons, Ltd (10.1111), 18(4), pp. 778-793. doi: 10.1111/rode.12118.

[21] Iamsiraroj, S. (2016) 'The foreign direct investment-economic growth nexus', International Review of Economics \& Finance. JAI, 42, pp. 116-133. doi: 10.1016/J.IREF.2015.10.044.

[22] Jugurnath, B., Roucheet, B. and Teeroovengadum, V. (2017) 'Moving To Greener Pastures: Untangling The Evidence About Fdi And Environmental Regulation In Eu Countries', Journal of Developing Areas. Tennessee State University, College of Business, 51(2), pp. 405-415.

[23] Kaur, J. (2013) 'FDI and Sustainabledevelopment: Lessons to Draw for India', Pune Annual Research Journal of Symbiosis Centre for Management Studies Annual Research Journal of SCMS, 1(1), pp. 56-68.

[24] Kirkulak, B., Qiu, B. and Yin, W. (2011) 'The impact of FDI on air quality: evidence from China', Journal of Chinese Economic and Foreign Trade Studies. Emerald Group Publishing Limited, 4(2), pp. 81-98. doi: 10.1108/17544401111143436.

[25] Klasra, M. A. (2011) 'Foreign direct investment, trade openness and economic growth in pakistan and turkey: an investigation using bounds test', Quality \& Quantity. Springer Netherlands, 45(1), pp. 223-231. doi: 10.1007/s11135-009-9272-5.

[26] Koroci, A. (2018) 'Does FDI infl uence economic growth in Albania?', Academic Journal of Business. Administration, Law and Social Sciences IIPCCL Publishing, 4(1).

[27] Lau, L.-S., Choong, C.-K. and Eng, Y.-K. (2014) 'Investigation of the environmental 
Kuznets curve for carbon emissions in Malaysia: Do foreign direct investment and trade matter?', Energy Policy. Elsevier, 68, pp. 490-497. doi: 10.1016/J.ENPOL.2014.01.002.

[28] Leiter, A. M., Parolini, A. and Winner, H. (2011) 'Environmental regulation and investment: Evidence from European industry data', Ecological Economics. Elsevier, 70(4), pp. 759-770. doi: 10.1016/J.ECOLECON.2010.11.013.

[29] Mihaylova, S. (2015) 'Foreign direct investment and income inequality in Central and Eastern Europe', Theoretical and Applied Economics, 12(2), pp. 23-42.

[30] Munir, K. and Sultan, M. (2017) Macroeconomic determinants of income inequality in India and Pakistan, Theoretical and Applied Economics. Winter.

[31] Ngwakwe, C. C. and Dzomonda, O. (2018) 'Foreign Direct Investment Inflow and Inequality in an Emerging Economy - South Africa', Acta Universitatis Danubius. Economica, 14(2).

[32] OECD (2013) Southeast Asian Economic Outlook 2013: with Perspectives on China and India - OECD.

[33] Omri, A., Nguyen, D. K. and Rault, C. (2014) 'Causal interactions between CO2 emissions, FDI, and economic growth: Evidence from dynamic simultaneous-equation models', Economic Modelling. North-Holland, 42, pp. 382-389. doi: 10.1016/J.ECONMOD.2014.07.026.

[34] Parezanin, M., Jednak, S. and Kragulj, D. (2016) 'The Impact of FDI on the Economic Growth of Serbia', Management - Journal for theory and practice of management, 21(78), pp. 25-32. doi: 10.7595/management.fon.2016.0003.

[35] Rasiah, R., Al-Amin, A. Q., Ahmed, A., Filho, W. L. and Calvo, E. (2016) 'Climate mitigation roadmap: assessing low carbon scenarios for Malaysia', Journal of Cleaner Production. Elsevier, 133, pp. 272-283. doi: 10.1016/J.JCLEPRO.2016.05.145.

[36] Ridzuan, A., Ismail, N., Che Hamat, A., Ridzuan, A. R., Ismail, N. A. and Che Hamat, A. F. (2017) 'Does Foreign Direct Investment Successfully Lead to Sustainable Development in Singapore?', Economies. Multidisciplinary Digital Publishing Institute, 5(3), p. 29. doi: 10.3390/economies5030029.

[37] Shahidan Shaari, M., Ermawati Hussain, N., Abdullah, H. and Kamil, S. (2014) 'Relationship among Foreign Direct Investment, Economic Growth and CO2 Emission: A Panel Data Analysis', International Journal of Energy Economics and Policy, 4(4), pp. 706-715.

[38] Sirag, A., SidAhmed, S. and Ali, H. S. (2018) 'Financial development, FDI and economic growth: evidence from Sudan', International Journal of Social Economics. Emerald Publishing Limited , 45(8), pp. 1236-1249. doi: 10.1108/IJSE-10-2017-0476.

[39] Solarin, S. A. and Shahbaz, M. (2015) 'Natural gas consumption and economic growth: The role of foreign direct investment, capital formation and trade openness in Malaysia', Renewable and Sustainable Energy Reviews. Pergamon, 42, pp. 835-845. doi: 10.1016/J.RSER.2014.10.075.

[40] Summit on Sustainable Development, W. (2002) Report of the World Summit on Sustainable Development - A/CONF.199/20. Available at: http://www.undocuments.net/aconf199-20.pdf (Accessed: 18 January 2019).

[41] Ucal, M., Hüseyin Bilgin, M., Haug, A. A. and Alfred Haug, P. (2014) Income Inequality and FDI: Evidence with Turkish Data, University of Otago Economics Discussion Papers. 1407. Turkey.

[42] Unctad (2014) World Investment Report 2014.

[43] Watson, R. T., Marufu C., Moss, R. H. and Dokken, D. J. (1997) The regional impacts 
of climate change: an assessment of vulnerability: summary for policymakers. Intergovernmental Panel on Climate Change. Available at: https://digital.library.unt.edu/ark:/67531/metadc11996/m1/3/ (Accessed: 18 January 2019).

[44] Wu, J.-Y. and Hsu, C.-C. (2012) 'Foreign direct investment and income inequality: Does the relationship vary with absorptive capacity?', Economic Modelling. NorthHolland, 29(6), pp. 2183-2189. doi: 10.1016/J.ECONMOD.2012.06.013.

[45] Xaypanya, P., Rangkakulnuwat, P. and Paweenawat, S. W. (2015) 'The determinants of foreign direct investment in ASEAN', International Journal of Social Economics. Emerald Group Publishing Limited , 42(3), pp. 239-250. doi: 10.1108/IJSE-10-20130238 . 